\title{
Gula Gending Dalam Sudut Pandang Budaya dan Perannya Menyokong Pendidikan Generasi Muda Desa Kembang Kerang
}

\author{
Sri Wahyuni ${ }^{1}$, Kaharuddin ${ }^{2}$ \\ ${ }^{1}$ wahyuni@staidk.ac.id, ${ }^{2}$ rudy220798@gmail.com \\ 12 Manajemen Pendidikan Islam, STAI Darul Kamal, Lombok Timur, Indonesia
}

\begin{abstract}
Abstrak
Gula gending merupakan sejenis jajanan khas yang berasal dari Desa Kembang Kerang yang begitu populer pada era 80an sampai 90an, terutama bagi anak-anak pada masa itu, sekaligus merupakan sebuah pertunjukan musik yang dimainkan ketika pedagang harum manis mempromosikan barang dagangannya untuk menarik perhatian calon pembeli. Gula Gending sering juga disebut sebagai jajanan khas Lombok (rambut nenek) yang di beberapa Daerah juga dikenal dengan beberapa sebutan, seperti gula kapas, harum manis, permen kapas (cotton candy). Kepopuleran gula gending dan banyaknya masyarakat kembang kerang memilih berprofesi sebagai pedagang gula gending membuat peneliti tertarik mengkaji lebih dalam bagaimana eksistensi gula gending dalam dinamika budaya Lombok ? dan seberapa besar perannya menyokong pendidikan generasi muda desa kembang kerang ?. Dengan melakukan studi kepustakaan peneliti mengkaji literatur terkait "gula gending". Sebagai wadah dari para pengrajin kuliner dalam menjajankan manisan tersebut, produk unggul yang lahir dari kearifan lokal ini telah mampu memberikan kehidupan yang lebih baik bagi warga masyarakatnya yang bermata pencaharian sebagai pengrajin dan penjual gula gending berkembang di lingkungan Desa Kembang Kerang Daya sebagai mata pencaharian masyarakat setempat. Alat pukul yang khas ini, hanya ada di Desa Kembang Kerang Daya dan kini merambah di Pulau Lombok sampai luar Daerah. Sehingga mereka mampu menyekolahkan anak-anak mereka hingga sarjana bahkan sampai doctor, tidak hanya itu, dari hasil berjualan gula gending mereka bisa pergi ke tanah suci Makkah untuk menunaikan ibadah haji. Analisis dilakukan terhadap fakta gula gending sebagai alat musik tradisional yang khas dengan keunikannya sudah dikenal sampai manca Negara serta eksistensinya dalam dinamika budaya Lombok.
\end{abstract}

Kata kunci: Gula gending, Budaya, Biaya Pendidikan

\section{Pendahuluan}

Keanekaragaman budaya seringkali menjadi daya tarik utama wisatawan mengunjungi tempat wisata. Lombok selain terkenal dengan pantainya yang indah dan megahnya gunung Rinjani, kebudayaan masyakarat Lombok juga menjadi sorotan dan daya Tarik wisatawan lokal dan internasional. Hampir setiap desa di Lombok memiliki 
budaya khas masing-masing. Desa kembang kerang sebagai salah satu desa di pulau Lombok memiliki kebudayaan yang mungkin belum banyak dikenal namun tumbuh subur dan harmonis dikehidupan masyarakat. Salah satu khas dari desa kembang kerang adalah "Gula Gending".

Desa Kembang Kerang Daya Kecamatan Aikmel Kabupaten Lombok Timur merupakan pusat kerajinan gula gending dan memiliki keunikan tersendiri dibandingkan dengan jajan lainnya. Karena gula merupakan komoditi penting bagi masyarakat Indonesia bahkan bagi masyarakat dunia. Kebutuhan akan gula dari setiap negara tidak hanya untuk memenuhi kebutuhan pokok, tetapi gula merupakan bahan pemanis utama yang digunakan sebagai bahan baku pada industri makanan dan minuman. Salah satunya, produksi gula gending yang berada di Desa Kembang Kerang Daya yang bahan bakunya berasal dari gula. Gula gending selain merupakan makanan khas juga merupakan salah satu kesenian tradisional khas Sasak Lombok. Dalam memainkan kesenian ini para pemain melakukannya sambil berjualan. Kesenian gula gending bisa dikatakan seni musik tradisional yang sudah mulai mendunia berkat perkembangan teknologi.

Gula gending berasal dari bahasa Sasak Lombok, yakni Gule (Gula) Frase istilah gula gending atau jika merujuk pada frase aslinya yang bersumber dari bahasa masyarakat Sasak di Pulau Lombok, Nusa Tenggara Barat, gule gending, mungkin masih banyak masyarakat nusantara yang belum (pernah) mendengar tradisi budaya unik yang lahir di Lombok, Nusa Tenggara Barat ${ }^{1}$. Musik dihasilkan dari tempat penyimpanan gula (katong yang terbuat dari bahan seng). Instrumen ini pertama kali dibuat di Desa Kembang Kerang, Lombok Timur oleh Almarhum Amaq Sakidep. Instrumen yang pertama kali dibuat sedikit berbeda dengan alat yang ada sekarang. Terjadi perkembangan pada jumlah kotak sumber suara yang pada mulanya berjumlah tiga buah kemudian menghilang sekitar tahun 1943

1 Kaekaha, 'Diaspora Gula Gending Lombok Melintas Negeri Untuk Eksistensi', Kompasiana, 2020 <https://www.kompasiana.com/kaekaha.4277/5f55d05c5218a06f5104b5f7/diaspora-gula-gending-lombokmelintas-negeri-untuk-eksistensi> [accessed 12 April 2021]. 
dan pada tahun 1945 muncul gula gending dengan kotak berjumlah enam buah ${ }^{2}$. Maka gula geniding kami sebut jajanan manisan yang tersimpan didalam kantong dan kantong tersebut sebagai alat musik yang bunyiaanya khas sehingga disebut sebagai alat tradisional. Jadi dapat disimpulkan bahwa gula gending adalah sejenis gulali atau manisan yang dijual dalam wadah yang sekaligus berfungsi sebagai gendang yang dimainkan untuk menarik calon pembeli.

Ada dua unsur sekaligus yang tertuang dalam gula gending ini, yakni unsur kesenian dalam wadah gendang dan juga unsur kuliner dalam gula gending atau manisannya. Pada tahun 90an para pedang gula gending memiliki persatuan Pedagang Gula Gending sehinga mereka mendapat undangan di acara besar yang diadakan oleh pemerintah Kabupaten, Provinsi NTB dalam menyambut tamu mancan negara kala itu ${ }^{3}$. Sehubungan dengan hal tersebut mereka sering mendapat undangan dalam dalam pembukaan acara tilawah di lapangan Aikmel Kecamatan Aikmel pada tahun 90an dan terkadang diundang pada acara perkawinan berkaloborasi dengan gendang belek akhir-akhir ini, tentu saja yang dipertontonkan hanyalah keahlian memainkan gendang, ini tentu saja menjadi sebuah atraksi yang menarik bagi masyarakat ${ }^{4}$.

Adapun cara menjual gula gending ini adalah dengan menggendong rombong dengan tali dari kain di salah satu bahu berkeliling kampung sambil membunyikan kantong belek sehingga tercipta sebuah alunan musik yang menarik minat pembeli. Di Beberapa tempat gula gending yang dijual ini juga ada, hanya saja yang membedakannya dengan yang ada di Lombok adalah cara berjualannya yang menggunakan gendingan sebagai alat

2 I Nyoman Triyanuartha, 'Eksistensi Gula Gending Di Dalam Dinamika Budaya Lombok', Journal of Urban Society's Arts, 2015 <https://doi.org/10.24821/jousa.v2i2.1445>.

${ }^{3}$ Hasil wawancara peneliti dengan Bapak Samal sebagai penggas kelompok pedang gula gending pada tanggal 1 januari 2021.

${ }^{4}$ Hasil wawancara peneliti dengan anggota kelompok gula gending bapak pahri pada tanggal 5 Januari 2021 
musik yang berfungsi juga sebagai wadah untuk membawa gula gending. Gula gending atau manisan yang memiliki daya tarik tersendiri bagi sebagai jajanan khas Desa Kembang Kerang Daya yang terbuat dari adonan tepung terigu dicampur dengan minyak goring di atas waccan dengan menggunakan api yang sedang, gula dan air direndam dengan takaran tertentu lalu dipanaskan sampai mendidih dengan tingkat kematangan tersendiri. Adonan tersebut sekali harus diaduk selama kurang lebih setengah jam, kemudian setelah matang diangkat dan diletakkan di atas lempengan aluminium lalu ditaburkan adonan tepung dan gula yang sudah siap lalu ditarik-tarik hingga menjadi berserabut yang di sebut (rambut nenek). Ada yang menyebutnya jajanan rambut uban karena bentuknya memang seperti uban, ada juga yang menyebutnya jajanan kumis kucing karena bentuknya juga memang mirip kumis kucing ${ }^{5}$. Untuk lebih tampak menarik adonan dicampur pewarna makanan.

Saat ini kebanyakan penjual gula gending adalah para lansia dan dilanjutkan oleh anak-anak muda yang siap menga kelertarian jajanan khas gula gending, kebanyakan dari mereka tetap melakukan kegiatan ini sebagai sumber peghasilan semata melainkan merasa terpanggil untuk tetap melestarikan kesenian tersebut, sangat jarang sekali anak muda yang mau untuk mempelajari kesenian tersebut, biasanya bakat ini diturunkan secara turun temurun dari generasi sebelumnya.

Penjual Gula gending juga sebagai pembuat gula gending (rambut nenek) yang tidak sembarangan orang bisa membuatnya, salah sedikit saja maka hasilnya akan rusak. Biasanya pembuatan gula gending ini adalah pada malam hari, kemudian keesokan harinya mulai dijual. Para Penjual gula gending biasanya mulai menjajakan jualannya sejak pukul 07.00 sampai menjelang matahari. Lokasi berjualannya biasanya jauh dari daerah asal, bahkan bisa sampai ke sebrang pulau, biasanya para penjual ini tidak akan pulang sebelum jualannya habis terjual, jika masih ada sisa, maka akan dilanjutkan keesokan hari, mereka

${ }^{5}$ Hasil wawancara dengan peneliti dengan salah anak penjualan gula gending kandidat doctor Symsul Wathani, M.Pd pada hari ahad 24 Januari 2021 
bahkan sampai menginap dimana saja sambil menunggu pagi berikutnya, jika sudah habis, barulah mereka pulang dan membuat lagi gula gendingnya.

Ciri Khas yang paling menonjol dari para penjual ini adalah keramahan dan juga semangat tidak putus asa untuk tetap berkeliling sambil memainkan gendingnya, hanya pada saat mereka beristirahat dan melayani pembeli saja mereka berhenti bermain, jika mereka memainkan musik berarti gula gendingnya masih ada, jika mereka berjalan atau sudah menaiki kendaraan maka itu berarti gula gending sudah habis, pantang bagi mereka untuk naik kendaraan jika masih ada jualannya, mereka akan tetap setia berjalan keluar masuk kampung mencari pembeli.

\section{Kajian Pustaka}

Identitas Pulau Lombok sebagai tempat berdiamnya suku Sasak antara lain ditandai oleh warisan budaya tak benda yang disebut gula gending. Gula gending merupakan salah satu jajanan kas Kembang-kerang yang menyerupai rambut nenek-nenek. Menurut Triyanuartha gula gending merupakan sebuah pertunjukan musik yang dimainkan ketika pedagang harum manis mepromosikan barang dagangannya untuk menarik perhatian calon pembeli ${ }^{6}$. Pertuntunjukan musik yang dimaksud Triyanuartha karena gula gending dijual dengan menggunakan sebuah instrument yang berbentuk kotak dengan beberapa sumber bunyi dan dimainkan untuk menarik perhatian calon pembeli. Sebelum menjual harum manis, pedagang akan memainkan musik terlebih dahulu. Kondisi inilah yang menjadikan sebutan gula gending. Hal ini merupakan kreativitas dari pedagang dalam memasarkan barang dagangannya. Tempat Gula gending saat ini memiliki bentuk setengah lingkaran terbuat dari kaleng dengan enam kotak di salah satu sisi sebagai sumber bunyi yang biasa disebut sebagai tangka'.

${ }^{6}$ Triyanuartha. 
Terdapat dua pendapat mengenai asal-usul nama gula gending. Pendapat yang pertama berdasar teknik pukul dan barang yang dijual maka instrumen itu disebut gule gending $(\text { gule }=\text { gula } \text {, gending }=\text { menabuh })^{7}$. Pendapat yang kedua lebih disebabkan karena alat ini untuk menjajakan semacam harum manis yang bahannya dari gula pasir maka musiknya disebut rombong .

Instrumen ini pertama kali dibuat di Desa Kembang Kerang, Lombok Timur oleh salah satu warga kembang kerang. Instrumen yang pertama kali dibuat sedikit berbeda dengan alat yang ada sekarang. Terjadi perkembangan pada jumlah kotak sumber suara yang pada mulanya berjumlah tiga buah kemudian menghilang sekitar tahun 1943 dan pada tahun 1945 muncul gula gending dengan kotak berjumlah enam buah.

A-D dan B-C adalah bagian tepi dari gula gending. A-D jaraknya 540mm sedangkan B-C jaraknya $310 \mathrm{~mm}$. Kotak 1 sampai dengan 6 tingginya $138 \mathrm{~mm}$, tebal $47 \mathrm{~mm}$, lebar $65 \mathrm{~mm}$, dengan jarak antara masing-masing kotak $60 \mathrm{~mm}$. E adalah lubang sebagai jalan untuk mengambil harum manis dengan garis tengah $120 \mathrm{~mm}$, sedangkan F merupakan tempat penyimpanan potongan kertas untuk pembungkus harum manis dengan garis tengah $150 \mathrm{~mm}$. Kotak yang berfungsi sebagai sumber nada adalah kotak 1 s.d. 5, sedangkan kotak ke-6 berfungsi untuk menyimpan uang. Kotak-kotak dari 1 s.d. 6 semuanya tidak tertutup. Nada-nada do, re, mi pada kotak gula gending tidak berurutan, bisa saja nada do di urutan kedua atau nada mi di urutan kelima9 ${ }^{9}$ Instrumen ini dimainkan dengan cara memukulkan 1 jari ke arah kotak kaleng dan jari yang dipukulkan bebas sesuai kemauan pemain. Keseluruhan kotak kaleng ialah enam buah namun yang digunakan untuk menghasilkan nada berjumlah lima buah. Lagu-lagu yang dapat dimainkan oleh pedagang

7 Khaerul Anwar. "Kadir Penyuluh Musik “Gule Gending” Lombok" dalam Kompas, Rabu 6 Oktober 2010

8 Dep DikBud. Ensiklopedi Musik dan Tari Daerah Nusa Tenggara Barat (LANJUTAN) 1978/1979

${ }_{9}^{9}$ Khaerul Anwar. 
gula gending antara lain: Semarang (Sembarang), Bua Oda (Pinang Muda), Tempong Gunung (Menembus Gunung), Enyek Setoe (tekan sebelah), Turun Tangis (mulai menangis) dan Bao Daya (teduh pikiran). Nama lagu-lagu tersebut menunjukkan situasi atau lambing.

Pada saat lagu dimainkan orang-orang yang tertarik mendengar bunyi-bunyi yang berasal dari keterampilan pedagang dalam memainkan gula gending akan berkumpul dan tidak jarang kemudian membeli harum manis yang dijual. Dapat dikatakan bahwa dimainkannya lagu dalam gula gending adalah sebagai cara untuk melakukan promosi terhadap harum manis kepada masyarakat.

Dahulu dalam menjajakan harum manis dilakukan oleh dua orang, seorang membawa tangka' dan yang lain membawa rincik yaitu Bagian-bagian gula gending. Tidak sedikit wisatawan belajar membuat sekaligus mempromosikan Gule Gending Desa Kembang Kerang Daya, Kecamatan Aikmel, Kabupaten Lombok Timur. Lewat Gule Gending pariwisata terangkat. Gule Gending, berkembang di lingkungan Desa Kembang Kerang Daya sebagai mata pencaharian masyarakat setempat. Alat pukul yang khas ini, hanya ada di desa tersebut dan kini merambah seantero Lombok, Sumbawa, dan daerah lain. Hebatnya, Gule Gending sudah dilirik oleh wisatawan Amerika sebagai kesenian yang unik. Sambil berjualan kembang gula, mereka memainkan Gule Gending.

Sebagai wadah dari para pengrajin kuliner dalam menjajankan manisan tersebut, produk unggul yang lahir dari kearifan lokal ini telah mampu memberikan kehidupan yang lebih baik bagi warga masyarakatnya yang bermata pencaharian sebagai pengrajin dan penjual Gule Gending. Para pedagang Gula Gending bahkan sudah menyentuh daerah ujung barat dan timur Indonesia. Hal itu bermula dari Lombok sekira tahun 1970 an, terus ke Sumbawa, Sumatera, Jawa, Kalimantan, Sulawesi, dan bahkan Papua. 
Ketenarannya Gule Gending pun menyita perhatian dua orang wisaawan mancanegara asal Amerika untuk mengetahui lebih dekat dan belajar lebih jauh. Kades Kembang Kerang Daya Kecamatan Aikmel Lotim, Daeng Muzakkir, SE., mengemukakan kedua wisatawan itu berniat untuk belajar bagaimana membuat Gula Gending tersebut. Menurutnya, lewat dua orang wisatawan tersebut nantinya Gula Gending bahkan Lombok akan lebih banyak dikenal oleh para wisatawan lainnya. Dengan demikian, hal tersebut bernilai promosi untuk lebih jauh ke arah pengembangannya dalam dunia pariwisata.

\section{Metode Penelitian}

Penelitian ini merupakan kualitatif deskriptif, terkait Gula Gending Didalam Dinamika Budaya Lombok dan perannya menyokong pendidikan generasi muda desa kembang kerang. Pengambilan dilakukan menggunakan metode wawancara dan studi literatur yaitu pengkajian mengenai konsep dan teori yang digunakan berdasarkan literatur yang tersedia, terutama dari artikel-artikel yang dipublikasikan dalam berbagai jurnal ilmiah. Narasumber yang peneliti wawancara adalah pelaku lansung (pedagang gula gending). Kajian pustaka berfungsi untuk membangun konsep atau teori yang menjadi dasar studi dalam penelitian.

\section{Pembahasan}

Gula Gending merupakan salah satu makanan bercita rasa manis yang hadir di Lombok, Nusa Tenggara Barat. Bisa dikatakan, makanan ini sangat mirip dengan gula gending. Ada yang menarik pada jajanan ini. Pasalnya, proses pembuatan Gula Gending disertai dengan alunan musik. Penjual yang menjajakan Gula Gending harus memukul wadahnya yang terbuat dari kaleng, hingga mengeluarkan irama musik tertentu. Nama Gule Gending berasal dari dua suku kata yakni gule berarti gula, dan gending yang berarti menebuh gendang. Gula Gending hadir dalam berbagai varian warna seperti putih, merah jingga, dan kuning. 
Wadah untuk menempatkan Gule Gending memiliki bentuk setengah lingkaran. Wadah ini terbuat dari seng dengan 6 kantong kotak di sisinya, dan 2 lubang box tempat menaruh gule gending yang akan dijual. Penjual yang menjajakan makanan ini harus menggendong wadah sembari memukul kaleng kotak yang berada di depannya sehingga mengeluarkan bunyi nyaring. Enam kantong kotak di depan wadah, berfungsi sebagai tangga nada seperti do, re, mi dan seterusnya.

Instrumen ini dimainkan dengan cara memukulkan 1 jari ke arah kotak kaleng dan jari yang dipukulkan bebas sesuai kemauan pemain ${ }^{10}$. Keseluruhan kotak kaleng ialah enam buah namun yang digunakan untuk menghasilkan nada berjumlah lima buah. Lagulagu yang dapat dimainkan oleh pedagang gula gending antara lain: Semarang (Sembarang), Bua Oda (Pinang Muda), Tempong Gunung (Menembus Gunung), Enyek Setoe (tekan sebelah), Turun Tangis (mulai menangis) dan Bao Daya (teduh pikiran).Nama lagu-lagu tersebut menunjukkan situasi atau lambing.

Pembuatan wadah ini sendiri memerlukan waktu mulai dari 1 sampai 4 pekan. Gule Gending dibuat dari adonan tepung terigu, gula, dan air yang digoreng dalam minyak panas. Cara membuat Gula Gending tergolong mudah, adonan harus selalu diaduk selama setengah jam. Selanjutnya, ketika adonan matang langsung diangkat dan diletakkan di atas lempengan aluminium.

Lalu, adonan gule gending ditarik-tarik kemudian ditaburkan tepung, hingga menjadi berserabut. Untuk lebih tampak menarik adonan dicampur pewarna makanan. Salah satu penjual yang menjajakan Gule Gending adalah Nasri. "Saya meneruskan usaha bapak saya, karena beliau sekarang sudah tidak berjualan lagi, saya yang menggantikan," kata Nasri. ${ }^{11}$

10 Wawancara, 13 Agustus 2010.

11 Viva.co.id, Selasa (7/10/2014). 
Dalam menjual Gule Gending, Nasri kerap menghadirkan lagu masa kini seperti boyband yang disukai anak muda. "Saya tidak hanya jualan, namun juga memberi hiburan lagu untuk pembeli. Lagu boybandanak muda sekarang juga bisa saya mainkan," tutup Nasri. Tidak sedikit wisatawan belajar membuat sekaligus mempromosikan Gule Gending Desa Kembang Kerang Daya, Kecamatan Aikmel, Kabupaten Lombok Timur. Lewat Gule Gending pariwisata terangkat.

Gule Gending, berkembang di lingkungan Desa Kembang Kerang Daya sebagai mata pencaharian masyarakat setempat. Alat pukul yang khas ini, hanya ada di desa tersebut dan kini merambah seantero Lombok, Sumbawa, dan daerah lain. Hebatnya, Gule Gending sudah dilirik oleh wisatawan Amerika sebagai kesenian yang unik. Sambil berjualan kembang gula, mereka memainkan Gendingan (musik).

Dalam memainkan kesenian ini para pemain melakukannya untuk menarik perhatian para pembeli. Kesenian Gule Gending bisa dikatakan seni musik tradisional yang sudah mulai langka. Kondisi ini berbeda jika kita flash back atau kembali ke beberapa tahun lalu, sekitar awal 1990-an. Saat itu, masyarakat tidak terlalu sulit menemukan pemain Gule Gending. Bahkan dalam satu hari bisa lebih dari seorang pemain Gule Gending dalam suatu wilayah atau kompleks perumahan.Gula Gending berasal dari bahasa sasak. Gule artinya permen, sedangkan gending artinya tetabuhan yang melahirkan bunyi-bunyian. Artinya, pemain Gule Gending menjual permen khas sasak sambil memainkan musik.

Permen atau gule yang disajikan dari dulu hingga sekarang tidak berubah. Permen yang terbuat dari bahan dasar gula dan tepung ini tetap berbentuk serabut-serabut berwarna-warni. Dalam menjual, para pedagang biasanya hanya menggunakan taplak dari selembar kertas berukuran sebesar piring kecil. Kertas ini digunakan sebagai alas untuk gula-gula saat dijual, supaya tidak menempel di tangan pembeli. Sedangkan gendingnya terbuat dari bahan seng dibentuk kotak-kotak segi empat. Dalam alat ini terdapat enam kotak. Untuk setiap kotak akan menghasilkan suara yang berbeda. Sehingga jika dipukul 
dengan jari secara bergantian akan menimbulkan suara musik dan lagu yang enak didengar dan khas. Dalam alat ini terdapat ruangan yang cukup luas untuk menyimpan gula-gula yang akan dijual. Nah suara alat musik inilah yang akan menjadi daya tarik. Sasaran utamanya anak-anak. Suara musik ini memancing khalayak berkumpul. Setelah ramai, secara tidak langsung barang dagangannya laku terjual. Dari segi jualan, Gule Gending merupakan salah satu makanan bercita rasa manis yang hadir di Lombok, Nusa Tenggara Barat.

Bisa dikatakan, makanan ini sangat mirip dengan gulali. Ada yang menarik pada jajanan ini. Pasalnya, proses pembuatan Gule Gending disertai dengan alunan musik. Penjual yang menjajakan Gule Gending harus memukul wadahnya yang terbuat dari kaleng, hingga mengeluarkan irama musik tertentu.

Profesi sebagai pedagan gula gending tentu terlihat sangat sederhana, mohon maaf kerapkali juga dianggap usaha "recehan". Tetapi dari profesi inilah sebagain besar anakanak di kampung kami menjadi sarjana, magister dan bahkan doktor. Sebab pengelanaan para penjual gula gending ke berbagai wilayah di Indonesia, selain bertujuan mencari rezeki untuk menyambung hidup, juga untuk biaya anak-anak mereka yang sedang sekolah dan atau kuliah. Maka tidak heran, sarjana-sarjana di kampung kami, yang kini sudah berprofesi sebagai guru, dosen, PNS dan lain-lain adalah sebagain besar anak-anak penjual gual gending.

\section{Kesimpulan}

Gula gending merupakan sebuah pertunjukan musik yang hidup di masyarakat Lombok sebagai perkembangan dari sarana promosi yang dilakukan pedagang harum manis. Musik ini dimainkan dengan cara menabuh instrumen gula gendingyang menghasilkan lima nada. Pola ritme yang dimainkan monoton. Untuk menghasilkan agar nada berbunyi lama dilakukan dengan cara memainkan nada pendek secara berulangulang. 
Keberadaan gula gending pernah menjadi langka di dalam masyarakat namun kini muncul kembali dan telah mengalami perkembangan. Berbagai inovasi telah dilakukan baik secara sonorik, visual, maupun kinestetik dari fungsinya sebagai sarana berdagang berkembang menjadi sebuah hiburan pariwisata. Hal ini terjadi karena perubahan budaya di Lombok yaitu dari agraris menuju pariwisata. Para pelaku gula gendingdengan demikian juga ikut mengalami perubahan sehingga para pedagang memiliki lembaga, status sosial, kelompok dan musikalitas yang baru.

\section{Daftar Pustaka}

Kaekaha, ‘Diaspora Gula Gending Lombok Melintas Negeri Untuk Eksistensi', Kompasiana, 2020<https://www.kompasiana.com/kaekaha.4277/5f55d05c5218a06f5104b5f7/dias pora-gula-gending-lombok-melintas-negeri-untuk-eksistensi> [accessed 12 April 2021]

Triyanuartha, I Nyoman, 'Eksistensi Gula Gending Di Dalam Dinamika Budaya Lombok', Journal of Urban Society's Arts, 2015 <https://doi.org/10.24821/jousa.v2i2.1445>

Anwar, Khaerul. 2010. “Kadir Penyuluh Musik "Gule Gending” Lombok” dalam Kompas, Rabu 6 Oktober 2010.

Pono Banoe, Kamus Musik, (Yogyakarta: Penerbit Kanisius, 2003).

Departemen Pendidikan dan Kebudayaan Pusat Penelitian Sejarah dan Budaya, Proyek Penelitian dan Pencatatan Kebudayaan Daerah. 1978/1979. Ensiklopedi Musik dan Tari Daerah Nusa Tenggara Barat (LANJUTAN).

Latifah Kodijat Marzoeki, Istilah-Istilah Musik, (Jakarta: Penerbit Djambatan, 2004)

Alan P. Merriam, The Anthropology of Music. (Illinois: University Press, 1964)

Jean-Jacques Nattiez. Music and Discourse Toward a Semiology of Music. Translated by Carolyn Abbate. Princeton: Princeton University Press, 1990).

https://kaskushootthreads.blogspot.com/2014/11/gulali-bermusik-khas-lombok-yangmulai.html 